\title{
ONE OUT, ONE IN
}

\author{
The greatest gift.
}

\section{BY AISLINN BATSTONE}

A nitta and her granddaughter walked the avenue between snow-topped graves on their way to the church for Mass. Copenhagen's Assistens Cemetery seemed an appropriate place for a conversation like this, even if Karin was being obstinate.

"Mormor, there's no way I'll allow you to do it," Karin said.

"I want to. You're ready to become a mother."

"Mathias and I might adopt. If not, we'll wait in the queue. I have frozen eggs."

"Oh, a firstborn at age 70? That makes sense. Like me being as healthy as a 60-yearold."

"Good. You'll live for another 40 years."

"Not if it denies you children. I had three babies, you know." Christian, so fat with his dark hair and high colour. Nikolaj with his thoughtful eyes and the way he always wanted to be close to her. And Karin's mother Josefine, a noisy child whose shrieks made strangers smile.

"It's a different world, Mormor."

"Not a different world. Just different ways."

Somewhere nearby, the philosopher and theologian Søren Kierkegaard lay sleeping in the frozen earth. A scattering of snow decorated the evergreens and the bare branches. Through the trees they glimpsed the green copper spire of the Holy Cross Church.

"The only thing I wish," Anitta said, "is that I could see you with your child. I picture it all the time. You in the hospital bed with your baby in your arms."

"One day Mathias and I will have a baby. Maybe one who really needs us. Then you will have your wish."

Anitta shook her head. There were plenty of couples and not enough orphans. Pregnancy, birth, feeding a baby with her own body. Why should Karin miss out because her own generation was too selfish to die? "We won't talk about it anymore. But if I die, my 'one out, one in' goes to you." Such a request was legally binding, she'd made sure of that.

"Thank you," Karin said, clearly relieved that the conversation was over.

Karin felt sick to her stomach the day she had her contraceptive implant removed. They'd gone from 237,000th in the queue to top of the list in one leap.

To think that she and Mathias would now be actively trying to make a new person. A new life that would start as a few cells in her womb and grow into an individual, a human being who would change her life.

She still felt shaky when she thought about what her grandmother had done for her. And now this nausea without even an embryo to cause it. Morning sickness. Mourning sickness. Traumatic to be handed the pot of a loved one's ashes and told that they had died so you could live a fuller life. A small comfort that the pot was her grandmother's favourite shade of blue. Had Mormor realized that Karin's life from now on would be joy and regret entwined like a helix of DNA?

A child! What would she do with a child? She only came across them every now and then, quiet little things surrounded by adults. Centenarians had taken over the playgrounds, whooping and swinging and sliding with their titanium hips and their fresh-grown organs.

"Ow!" Karin winced as the doctor injected local anaesthetic in her upper arm.

"Now hold still while I dig it out," the doctor said.

"So sweet. He looks like your uncle Nikolaj." Josefine, Karin's mother, curled her index finger into the newborn's hand. "Can I take care of him sometimes?"

"Of course, Mor. You're the third person who's asked. Actually, can you look after him on the night of our wedding anniversary? May 18th?"

"I'm sorry, Eric is taking me skiing that weekend."

Oh, that was just like her mother. But someone else would willingly babysit. "Help me feed him?"

"Here. I'll hold him while you get ready. What are you going to call him?"

"Maybe Nikolaj." Karin accepted the bundle from her mother. She brought his $\rightarrow$ NATURE.COM

Follow Futures: @NatureFutures

f go.nature.com/mtoodm head close to her breast and felt the strange sensation of a string twanging through the centre of her body as the baby sucked and brought down her milk. "I wish Mormor could have met him."

"She looks so happy." Anitta touched Karin's cheek on the screen. It was wet, like her own.

She turned to face her guard. "The government has been extremely generous."

"It's time now," he said.

"I know." Last year they had interviewed her four times, asking her about the gold cross she wore around her neck and whether she was sure she wanted to take 'such a step.' My relationship with God is personal. God wants what is best for me and my family.

Anitta followed the guard out of the room and along the hospital corridor. They would give her the injection in the comfortable room she'd slept in since her 'death' over a year ago. They'd been so accommodating. She was truly grateful.

A nurse's warm hand covered hers, soothing the fear that fluttered like a moth in her chest. There'd been worse moments in her life, sickening fears, mostly involving her children and their accidents. In comparison, this was a question mark, equal parts hope and fear.

Death began with a beautiful dream.

A small girl playing in the snow. A young woman at university. A ringing of church bells. A mother with her first child.

Karin and her baby, dark-eyed Nikolaj. Anitta held him in her arms. She felt him grow chubby and tall. The smell of his hair. The softness of his skin.

The sound of the bells, snow on the gravetops.

Love blossoming into unbearable ecstasy. Fireworks, noise.

Silence. Dark.

Peace.

Perfect peace.

Aislinn Batstone is no longer a practising Catholic, scientist or philosopher, but she is a practising mother. Always practising, never perfect, but the kids seem to be turning out $O K$. 